\title{
Distance to the Frontier and Innovation: The Role of Local Business Environment
}

\author{
Pham Thi Huyen Trang \\ Vu Hoang Nam ${ }^{b}$ \\ Foreign Trade University
}

\begin{abstract}
This study uses panel data from biennially surveys of small and medium-sized enterprises during the period of 2005-2015 in the transition economy of Vietnam, and data on the quality of local business environment (measured by the provincial competitiveness index). This study uncovers that the effects of distance to the frontier (measured by the ratio of productivity of an enterprise to that of the industry leader) on innovation are negatively moderated by improved local business environment. Such an important role of the local business environment indicates that laggard enterprises, which form the majority in transition economies, are favourably supported to achieve innovation when quality of the local business environment is improved.
\end{abstract}

Keywords: Innovation, frontier, business environment, Vietnam

JEL classification: O31, O33, L22

\section{Introduction}

The literature shows that in coping with rising competition, pioneer enterprises carry out research and development (R\&D) aimed at gaining innovation (Aghion, Bechtold, Cassar \& Herz, 2014; Culbertson \& Mueller, 1985; Lunn \& Martin, 1986). As a result of trials and errors, some enterprises fail to innovate and lag behind, while others advance to achieve innovation. The pioneers with innovation will become the leaders and gain high profit. Such high profit attracts other following enterprises to carry out innovation, which may endanger the leading position of the leaders. The spiral rounds of innovation carried out by both the leaders and the followers take place (Sonobe \& Otsuka, 2006).

Nevertheless, there is a gap in the literature about understanding whether these groups of enterprises are distinct in terms of achieving innovation. A few exceptions include Acemoglu, Aghion and Zilibotti (2006) and Aghion, Blundell, Griffith, Howitt and Prantl (2006). In these studies, the authors underline how distance to the frontier, which refers to the distance or closeness of a firm's technology to the leader in the industry, determines innovation of different categories of the followers. Similarly,

a School of Economics and International Business, Foreign Trade University, No. 91 Chua Lang St., Dong Da District, Hanoi, Vietnam. Email: trang.pham@ftu.edu.vn

b Faculty of International Economics, Foreign Trade University, No. 91 Chua Lang St., Dong Da District, Hanoi, Vietnam. Email: namvh@ftu.edu.vn (Corresponding author)

* This research is funded by Vietnam National Foundation for Science and Technology Development (NAFOSTED) under grant number 502.01-2018.03. 
there is a large body of literature confirming that heterogeneity in firm innovation exists among different categories of firms given their size and age (Lunn \& Martin, 1986; Mansfield, 1981; Scherer, 1965; Scott, 1984). Enterprises in Vietnam are not an exception. According to Nhung (2018), spending on R\&D and innovation is mainly performed by large and foreign-invested enterprises in Vietnam. Their spending on R\&D accounted for $70 \%$ of total R\&D expenditure and $77 \%$ of total innovation spending. Non-state enterprises accounted for only $27 \%$ of R\&D spending and $19 \%$ of spending on innovation. Of the total revenue brought by innovation, $98 \%$ was made up of large enterprises (Nhung, 2018).

Regarding business environment and innovation of enterprises, a great number of studies have analysed how the latter is determined by the former (Aghion \& Howitt, 1992; Aghion, Bloom, Blundell, Griffith, \& Howitt, 2005; Aghion, Harris, Howitt, \& Vickers, 2001; Barbosa \& Faria, 2011; Caballero \& Jaffe, 1993; Schumpeter, 1934). As the number of small and medium-sized enterprises (SMEs) accounts for the largest proportion of the total number of enterprises in Vietnam (Nguyen, Pham, Nguyen, \& Nguyen, 2008) - which is typically similar to other transition economies - policies to support the SMEs to innovate is on top of the development agenda of the government of Vietnam. The government has been promoting innovation of the SMEs in various ways, of which reforming institutions is among priority policies. Over the last decade, reforming institutions by improving business environment for promoting enterprise development has been considered the key for spurring economic growth (Vo, 2015). Understanding to what extent an improved business environment moderates the effects of distance to the frontiers on innovation of enterprises is, however, limited.

Using a panel of data from surveys of SMEs conducted biennially during the period of 2005-2015 in ten provinces in Vietnam and data on local business environment (measured by the provincial competitiveness index $(\mathrm{PCI})$ ), this study confirms that improved local business environment negatively moderates the effects of distance to the frontier (measured by the ratio of productivity of an enterprise to that of the industry leader) on innovation of SMEs in Vietnam. Furthermore, the study uncovers that the effects of distance to the frontiers on innovation of enterprises are contingent on the size and age of enterprises. Specifically, the negative explanatory role of the local business environment on the effects of distance to the frontiers on innovation is stronger among micro-sized and young enterprises. Regarding different types of innovation, we find that these effects are more significant for incremental innovation. These findings suggest that the SMEs that are lagging behind compared to their rivals are more favoured to achieve innovation, which are mostly incremental, in the improved local business environment in a transition economy.

The rest of the paper is organised as follows. The second section presents a theoretical framework. The third section discusses methodology and data. The fourth section shows estimation results. Concluding remarks are provided in the final section.

\section{Theoretical Framework}

A growing body of literature has highlighted various firm-specific or internal factors and external factors such as region-specific separately affecting firms' innovation (Acs \& 
Audretsch, 1990; Block, Fisch, \& Praag, 2016; Cobbenhagen, 2000; Sternberg \& Arndt, 2001). According to the firm's innovation behaviour model proposed by Sternberg \& Arndt (2001), internal factors include industry and market position, organisational status, R\&D, planning and marketing functions, competences of staff, financial resources, attitude of management and staff towards innovation, and innovation networks. In this model, the foremost factor is industry and market position, which determines firms' innovation because it forces firms to carry out permanent innovation or aggressive pricing to maintain their competitiveness (Sternberg \& Arndt, 2001). A great number of previous studies have used distance to the productivity of the frontier in the industry to proxy for market position of a firm. Aghion et al. (2006) argued that the effect of entry on productivity growth is more positive as a firm is closer to the productivity frontier. Alder (2010) found that firms with more advanced technology and productivity compared to their main competitors have more product innovation. Hölzl and Janger (2014) confirmed that innovation increases as firms approach the technological frontier because they need to focus on creating their own knowledge and adopt innovation-based growth strategies to remain competitive. In this study, we focus on the market position factor taking distance to the frontier in the industry in terms of productivity as a proxy. In other words, we consider a relative productivity position of a firm to its frontier in the industry as an important internal factor for firms' innovation.

Among other internal factors, firm size is often taken as a key determinant of firm's innovation but results on effects of firm size on firm's innovation are mixed. Firm size is the first internal factor in the model proposed by Sternberg \& Arndt (2001) that supports a positive correlation with process innovation. Firm size is also shown to be positively correlated with innovation in other studies by Lunn and Martin (1986) and Mansfield (1981). Rothwell (1985) and Vossen (1998) further confirmed the role of firm size on innovation of both small and large firms as it plays complementary roles in the process of technical advance. Nevertheless, other studies report a negative or no relation between firm size and firm's innovation (Scherer, 1965; Scott, 1984). Apart from firm size, firm age is another important factor affecting firm's innovation. Huergo and Jaumandreu (2004) suggested that entrant firms have the highest probability of innovation, while the older firms experience a lower probability of innovation. Balasubramanian and Lee (2008) agreed and showed that firm age is negatively related to technical quality. Coad, Segarra and Teruel (2016) also confirmed the role of firm age in determining innovation and firm growth.

Regarding external factors of firm's innovation, Sternberg and Arndt (2001) argued that three groups of external factors covering location factors of the region, technology and innovation policy, and overall firm environment affect firm's innovation. Nevertheless, they only used several variables to proxy for the first group which is location factors of the region in their estimation and were silent about the remaining two groups. Previous studies in the literature also discuss how the local business environment, which is considered as a broad external factor, affects innovation of firms. Brouwer, Budil-Nadvornikova and Kleinknecht (1999) showed that firms in urban agglomerations have a higher share of their R\&D to develop new products and higher probabilities of announcing new products in journals. Kleinknecht and Poot (1992) also suggested that characteristics of regions affect R\&D. Audretsch, Hülsbeck and 
Lehmann (2012) argued that regional competitiveness and university spillovers have a positive effect on start-up innovation. Block et al. (2016) emphasised the role of environment through regional clusters and knowledge spillover effects on innovative entrepreneurship. Following the literature, we are interested in the role of local business environment in influencing firm's innovation in this study.

Findings on joint effects of these internal and external factors on firm's innovation are, however, limited. Even though Sternberg and Arndt (2001) proposed various internal and external factors affecting firm's innovation behaviour, the study does not provide any insights into interaction among these factors which may affect firm's innovation behaviour. A few exceptions including Slappendel (1996) have discussed the interactive and temporal context of the process. Indeed, little has been mentioned about effects of multi-factors and interlinks between these factors on innovation of firms (Edwards, Delbridge \& Munday, 2005). For example, there is a gap in the literature about differences between a few innovative firms and the majority of new and noninnovative firms and the link between these types of firms in the same development context. An exception is a recent study by $V u$ and Hoang (2019) that emphasises how innovation persistence of Vietnamese SMEs is eliminated in a better business environment. Nevertheless, it does not directly provide insights into how improved business environment affects firms in different market positions. In other words, failure to link between entrepreneurship and innovation may lead to ineffective policies to promote growth through encouraging more people to become entrepreneurs (Block et al., 2016).

As a result, in this study we propose a framework to analyse the interaction between market position, which is proxied by distance to the frontier in terms of productivity in the industry, and the local business environment in jointly determining innovation of firms apart from other internal factors. We argue that in addition to separate effects of each internal and external factor there exists significant impact of interlinks between market position, which is one of the most important internal factors, and the local business environment, which is a broad external factor.

\section{Methodology and Data}

\subsection{Methodology}

We follow Amable, Demmou and Ledezma (2008) and Malva and Santarelli (2016) in estimating the effects of internal and external factors on innovation of the SMEs. Specifically, the estimation specification is as follows:

$$
\begin{aligned}
\text { Innovation }_{i t}= & \beta_{0}+\beta_{1} \text { Dist }_{i t}+\beta_{2} P C l_{j t}+\beta_{3} \text { Dist }_{i t} \text { InPCl }_{j t}+\beta_{4} \text { Size }_{i t}+\beta_{5} \text { Age }_{i t}+ \\
& \beta_{6} D+\mu_{i}+\varepsilon_{i t}
\end{aligned}
$$

in which Innovation $_{i t}$ is a set of dummies measuring various specific types of innovation of the SMEs including introduction of new products, improvement of existing products and introduction of new production process. In addition, we measure the general innovation of the SMEs by taking the value of Innovation $_{i t}$ as 1 if an SME has achieved any of the three types of innovation mentioned above and 0 otherwise. 
Dist $_{i t}$ measures distance to the frontier of enterprise $i$ at time $t$. Distance to the frontier is measured by the distance of productivity between firm $i$ and its leader in the same industry. We follow Amable et al. (2008) and Malva and Santarelli (2016) to measure distance to the frontier as a ratio of labour productivity of an SME relative to that of its industry's leader, in which labour productivity is measured by value-added divided by the total labour force. The industry leader is the firm that has the highest labour productivity of that industry in the sample. According to the literature, distance to the frontier is expected to be positively associated with innovation of a firm as those which have productivity close to the levels of frontiers in their industries would increase their innovation activities to escape competition.

$P C l_{j t}$ is an index to measure quality of the local business environment of province $j$ where an SME is located at time $t$. The local business environment is an external factor that influences a firm's innovation. Business environment refers to many aspects including economic, legal, political and social activities (Barbosa \& Faria, 2011). There are different ways to select variables to present local business environment. North (1990) and Hwang and Powell (2005) considered changes in business environment as a process of making rules, creating laws, or supporting the efforts of certain groups and retarding those of others. Barbosa and Faria (2011) refer to business environment as administrative and economic practices and policies that regulate the product, labour and capital markets. Vo (2015) uses the favourable treatment of the state-owned firms, private firm promotion policy, labour availability and corruption of local government as main components of the business environment in their research on performance of Vietnam SMEs.

In this study, we use the provincial competitiveness index (PCI) to proxy for the quality of the local business environment. The $\mathrm{PCl}$ index has been constructed yearly for all 63 provinces in Vietnam since 2005 by the Vietnam Chamber of Commerce and Industry ( $\mathrm{VCCl}$ ) and USAID through surveys of a wide range of local enterprises. This index is based on enterprises' assessment of various aspects of the local business environment. It is a composite index that contains ten sub-indices for: 1) entry costs for business start-up, 2) access to land and security of business premises, 3) business environment and business information, 4) informal charges, 5) time requirement for bureaucratic procedures and inspections, 6) crowding out of private activity from policy biases toward state, foreign, or connected firms, 7) provincial leadership in solving problems for enterprises, 8) business support services, 9) labour training policies, and 10) legal procedures for dispute resolution $(\mathrm{VCCl}, 2018)$. The value of $\mathrm{PCl}$ is from 0 to 100. The higher the index, the better the quality of the local business environment. Therefore, we decided to use the $\mathrm{PCl}$ index as a proxy for quality of the local business environment in Vietnam.

The quality of the local business environment affects innovation of firms directly and indirectly. Directly, in a local business environment with higher quality more efficient allocation of valuable resources will be realised to support innovative activities of firms. Also, cost of conducting innovation in high-quality business environment is lower. Indirectly, the local business environment affects competition in the market which in turn determines innovation of firms (Barbosa \& Faria, 2011). 
The Schumpeterian model suggests a negative relationship between competition and firm innovation as the former lowers gains from the latter (Schumpeter, 1934). It is argued that higher market competition reduces the flow of rents and, hence, lower incentives for innovating (Aghion \& Howitt, 1992; Caballero \& Jaffe, 1993). Crepon and Duguet (1997) also confirmed a negative impact of competitor's R\&D on a firm's innovation. Nevertheless, Aghion et al. $(2001,2005)$ extended the traditional Schumpeterian endogenous growth model to take into account the heterogeneity of firms' productivity levels and found that there are positive effects in industries where competitors have comparable productivity levels, i.e. the so-called neck-to-neck competition. A more intense competition environment induces firms to innovate to escape from competition and capture the leading position in the industry. In industries where there is a big gap between the frontiers and a majority of the laggards, the Schumpeterian effect would be stronger, thus causing an inverse U-shape relationship between competition and innovation. Recent studies also find that harder imitation and stronger patent protection should raise R\&D incentives by extending the expected duration of rents from innovation (Aghion et al., 2005; Conway, de Rosa, Nicoletti, \& Steiner, 2006; Davidson \& Segerstrom, 1998; Zeng, 2001). Even though the quality of local business environment affects innovation of firms directly and indirectly, separating these two effects in this study was not possible given the availability of information provided in the dataset. Therefore, as a limitation of the study we could only capture the aggregate effects of the quality of local business environment on innovation of the SMEs.

Our main interest is on $\beta_{3}$, which is the coefficient of the interaction term between distance to the frontier and $\mathrm{PCl}$. This interaction term captures the joint effects of the quality of local business environment and of distance to the frontier on innovation of the SMEs. If $\beta_{3}$ is smaller than zero, a better-quality local business environment promotes innovation of the laggards, which supports the Schumpeterian model. In other words, improved quality of the local business environment favours the SMEs having low productivity, which accounts for the majority of the SMEs in Vietnam.

Firm size and firm age are important internal factors that determine innovation of the SMEs. Therefore, the variables representing firm size and firm age are incorporated in the empirical model. Firm size is measured by the total number of regular workers. Firm age is measured by number of years since establishment. Both are in log form.

$D$ is a vector of factorial variables included in Equation (1) to control for industry, location and year dummies. $\mu_{i}$ captures the time-invariant factors that affect innovation of the SMEs. $\varepsilon_{i t}$ is the normal error term.

Estimation of Equation (1) potentially contains an endogeneity problem as the distance to the frontier and innovation could hold a simultaneous relation. The enterprises that are closer to the frontier might become more innovative in order to escape competition. At the same time, the enterprises that achieve innovation increase their productivity and become closer to the frontier. Unfortunately, we are not able to find a good instrumental variable to conduct the 2SLS estimation, which is the best method to deal with the endogeneity problem. As a result, on the right-hand side of Equation (1), instead of using distance to the frontier of the current period, we use its lag for one period to avoid the reverse causality from current innovation to distance to the frontier. The equation to estimate is as follows: 


$$
\begin{aligned}
\text { Innovation }_{i t}= & \beta_{0}+\beta_{1} \text { Dist }_{i t-1}+\beta_{2} P C l_{j t}+\beta_{3} \text { Dist }_{i t-1} \text { InPCl }_{j t}+\beta_{4} \text { Size }_{i t}+\beta_{5} \text { Age }_{i t}+ \\
& \beta_{6} D+\mu_{i}+\varepsilon_{i t}
\end{aligned}
$$

A summary of all variables is presented in Table 1. To estimate Equation (2) we applied the logit random effects model for panel data.

\begin{tabular}{|c|c|}
\hline \multicolumn{2}{|l|}{ Dependent variable } \\
\hline Innovation & $\begin{array}{l}\text { Dummy variable: equals } 1 \text { if an SME achieves at least one of three } \\
\text { types of innovation: } 1 \text { ) new products, } 2 \text { ) improvement of existing } \\
\text { products, 3) new production process, equals } 0 \text { otherwise. }\end{array}$ \\
\hline New products & $\begin{array}{l}\text { Dummy variable: equals } 1 \text { if an SME introduces new products, equals } 0 \\
\text { otherwise. }\end{array}$ \\
\hline $\begin{array}{l}\text { Improvement of existing } \\
\text { products }\end{array}$ & $\begin{array}{l}\text { Dummy variable: equals } 1 \text { if an SME improves existing products, equals } \\
0 \text { otherwise. }\end{array}$ \\
\hline New production process & $\begin{array}{l}\text { Dummy variable: equals } 1 \text { if an SME introduces new production } \\
\text { process, equals } 0 \text { otherwise. }\end{array}$ \\
\hline \multicolumn{2}{|l|}{ Independent variables } \\
\hline $\mathrm{PCl}$ & $\begin{array}{l}\text { Provincial Competitiveness Index to measure quality of the local } \\
\text { competitive environment, measured in log form. }\end{array}$ \\
\hline Distance to the frontier & $\begin{array}{l}\text { Ratio of labour productivity relative to that of the frontier in the same } \\
\text { industry. }\end{array}$ \\
\hline Size & Firm size, measured by total number of regular workers, in log form. \\
\hline Age & Years of establishment, in log form. \\
\hline Location & Dummy variable: representing 10 provinces covered in the surveys. \\
\hline Industry & Dummy variable: industry classification by VISIC at 2 digit level. \\
\hline Year & Dummy variable: for year 2005, 2007, 2009, 2011, 2013 and 2015. \\
\hline
\end{tabular}

Table 1. Description of variables

Source: Authors' compilation.

\subsection{Data}

The data used in this empirical study are taken from the Vietnam small and mediumsized enterprises surveys conducted biannually during the period of 2005-2015. These surveys were conducted by the Institute of Labor Science and Social Affairs (ILSSA) under the Ministry of Agriculture and Rural Development of Vietnam and the Central Institute for Economic Management (CIEM) in Vietnam with the technical support from Copenhagen University in Denmark. The dataset contains information to allow us to calculate the labour productivity of SMEs. Information on three different types of innovation which are introduction of new products, improvement of existing products and introduction of new production processes is included. Data on other characteristics of the SMEs are also available. 
These surveys were conducted for manufacturing SMEs in 10 provinces in Vietnam. The number of sampled SMEs in each survey is reported in Table 2. In each survey, some SMEs were excluded due to exit and were replaced by other randomly selected SMEs. Therefore, an unbalanced panel of data with a total of 5,132 SMEs existing in multiple years during the period of 2005-2015 is used for analysis in this study.

Table 2. Number of sampled SMEs

\begin{tabular}{cc}
\hline Year & Number of sampled enterprises \\
\hline 2005 & 2,821 \\
2007 & 2,617 \\
2009 & 2,649 \\
2011 & 2,539 \\
2013 & 2,518 \\
2015 & 2,647 \\
\hline
\end{tabular}

Source: Authors' calculation.

The sampled SMEs were in various industries according to the Vietnam Standard Industry Classification (VISIC). Several major industries include fabricated metal, food and beverages, wood, furniture, rubber and textiles. The majority of SMEs (72\%) are household enterprises which are micro and small size according to the enterprises' classification of Vietnam. ${ }^{1}$ The number of SMEs classified by size and age is presented in Table 3.

Table 3. Number of sampled SMEs by size and age in 2015

\begin{tabular}{lrc}
\hline By size & Number of enterprises & \% of total enterprises \\
\hline Micro & 1,992 & 75.25 \\
Small & 589 & 22.25 \\
Medium & 66 & 2.50 \\
\hline By age (years of establishment) & & \\
1 -10 years & 402 & 14.96 \\
$11-20$ years & 1,281 & 48.39 \\
$21-30$ years & 683 & 25.80 \\
More than 30 years & 281 & 10.85 \\
\hline
\end{tabular}

Source: Authors' calculation.

1 According to the law of Vietnam, enterprises in Vietnam are classified into four groups with micro, small, medium and large size. Micro enterprises have less than 10 workers. Small enterprises have from 10 to less than 200 workers. Medium enterprises have from 200 to less than 300 workers. Large enterprises have 300 or more workers. 
Information to measure the quality of local business environments is taken from the Provincial Competitive Index $(\mathrm{PCl})$ dataset conducted and released annually by the Vietnam Chamber of Commerce ( VCCI) and the US Agency for International Development (USAID). Besides, data on Vietnam GDP deflators provided by the World Bank (World Bank, 2017) are used to calculate the real values of variables.

\section{Results and Discussion}

Tables 4 and 5 report regression results of the estimation of Equation (2). In Table 4, the regression results present effects of distance to the frontier on general innovation of the SMEs which takes on the value of 1 if an SME achieves at least one of three types of innovation and 0 otherwise. The results show that distance to the frontier is positively and significantly associated with innovation. This finding is in line with other studies in the literature, that as firms are getting closer to the frontiers they are more likely to pursue an innovation-based strategy, focusing on creating their own knowledge (Acemoglu et al., 2006).

The coefficient of local business environment variable is negative and highly significant in Table 4, implying that the Schumpeterian model is supported and the SMEs tend to innovate less when the competition is increasing in an improved business environment. According to Aghion et al. (2001, 2005, 2014), increased competition might reduce the post-innovation rents of firms and thus, their incentive to catch up with the leader. That increased competition boosts innovation normally happens in sectors where incumbent firms are operating at similar levels or "neck-to-neck" sectors. Nonetheless, this might not be the case for the Vietnamese SMEs as in most of the provinces the gap between the leaders and the laggards is large.

Table 4. Effects of distance to the frontier on general innovation of SMEs

\begin{tabular}{lc}
\hline Dist $_{t-1}$ & $26.162^{* *}$ \\
InPCl $_{j t}$ & $(2.33)$ \\
& $-1.616^{* * *}$ \\
Dist $_{i t-1} \operatorname{lnPCl}_{j t}$ & $(4.01)$ \\
Firm size & $-6.561^{* *}$ \\
& $(2.36)$ \\
Firm age & $0.447^{* * *}$ \\
& $(18.65)$ \\
Industry dummies & $-0.272^{* * *}$ \\
Location dummies & $(4.39)$ \\
Year dummies & Yes \\
Constant & Yes \\
& Yes \\
No. of observations & $6.309^{* * *}$ \\
\hline
\end{tabular}

Note: Absolute value of $\mathrm{z}$ statistics in parentheses; * significant at $10 \%,{ }^{* *}$ significant at $5 \%, * * *$ significant at $1 \%$.

Source: Authors. 
Table 5. Effects of distance to the frontier on specific types of innovation of SMEs

\begin{tabular}{lccc}
\hline & $\begin{array}{c}\text { New } \\
\text { product }\end{array}$ & $\begin{array}{c}\text { New production } \\
\text { process }\end{array}$ & $\begin{array}{c}\text { Improvement of } \\
\text { existing products }\end{array}$ \\
\hline Dist $_{t-1}$ & -12.747 & -0.383 & $36.830^{* *}$ \\
InPCI $_{j t}$ & $(0.49)$ & $(0.03)$ & $(3.02)$ \\
& $-1.582^{* *}$ & $-2.073^{* * *}$ & $-2.199^{* * *}$ \\
Dist $_{i t-1}$ InPCI $_{j t}$ & $(2.00)$ & $(3.36)$ & $(4.85)$ \\
& 3.113 & -0.040 & $-9.263^{* * *}$ \\
Firm size & $(0.49)$ & $(0.01)$ & $(3.05)$ \\
& $0.197^{* * *}$ & $0.709^{* * *}$ & $0.482^{* * *}$ \\
Firm age & $(5.36)$ & $(20.54)$ & $(17.62)$ \\
& -0.065 & $-0.405^{* * *}$ & $-0.350^{* * *}$ \\
Industry dummies & $(0.66)$ & $(3.95)$ & $(4.76)$ \\
Location dummies & Yes & Yes & Yes \\
Year dummies & Yes & Yes & Yes \\
Constant & Yes & Yes & Yes \\
& $7.485^{* *}$ & $5.148^{* *}$ & $6.094^{* * *}$ \\
No. of observations & $(2.28)$ & $(1.99)$ & $(3.21)$ \\
\hline
\end{tabular}

Note: Absolute value of $z$ statistics in parentheses; * significant at $10 \%, * *$ significant at $5 \%,{ }^{* * *}$ significant at $1 \%$.

Source: Authors.

The coefficient of the interaction term between distance to the frontier and business environment, which is our main interest is negative and highly significant. This finding indicates that the improved local business environment supports the laggards who have low productivity compared to the frontiers in their industries. As the laggards which account for the majority of all SMEs are considered as weaker and more backward, this finding implies that an improved local business environment is important to promote innovation for the majority of the SMEs. Given the fact that innovation of the SMEs is generally more incremental than disruptive even with types such as the introduction of new products or new production process, such scenario might be more socially desirable than the case where favour for innovation is given only to strong and leading enterprises because it can help to support the majority of SMEs.

Results in Table 5 present the effects of distance to the frontier, local business environment and the role of improved local business environment on specific types of innovation achieved by the SMEs. While the Schumpeterian effects of the local business environment prevail in all types of innovation achieved by the SMEs, we do not observe any effect of distance to the frontier and the role of local business environment on the introduction of new products and new production process. Distance to the frontier only shows its positive effect on the improvement of existing products. Similarly, the significant effect of the interaction between the improved local business environment and distance to the frontier is only observed on the improvement of existing products, implying that improved local business environment only favours the laggards in carrying out and achieving incremental innovation. More radical innovation, i.e. introduction 
of new products and introduction of new production process, requires more than just an improved local business environment. These findings in Table 5 are consistent with and strengthen the findings in Table 4, suggesting that recent efforts of the local governments in Vietnam to improve quality of their local business environment are effective in supporting the SMEs, which account for the majority of enterprises, to innovate. These results are in line with previous studies that show the existence of Schumpeterian effects such as Amable et al. (2008).

In both Tables 4 and 5, we find that larger SMEs innovate more than their smaller counterparts as the coefficients of firm size are positive and significant. This finding is in line with previous studies that support the positive correlation between firm size and innovation (Lunn \& Martin, 1986; Mansfield, 1981). Findings in both tables also show that young SMEs have achieved more innovation than aged ones, which is consistent with previous studies indicating a negative relationship between firm age and innovation (Balasubramanian \& Lee, 2008; Hansen, 1992; Huergo \& Jaumandreu, 2004).

Graphically, the marginal effects of distance to the frontier and of local business environment on innovation are illustrated in Figure 1 and Figure 2. Figure 1 presents the marginal effects of distance to the frontier on innovation plotting over a range of values of $\mathrm{PCl}$. We find a decreasing pattern of marginal effects of distance to the frontier on innovation along increasing values of $\mathrm{PCl}$. As the local business environment is improved the positive effects of distance to the frontier on the probability of achieving innovation decrease. In other words, in an improved local business environment the SMEs that are close to the frontier in terms of productivity are less likely to innovate. The laggards, which have lower productivity and are far from the frontier, tend to achieve relatively more innovation than their counterparts.

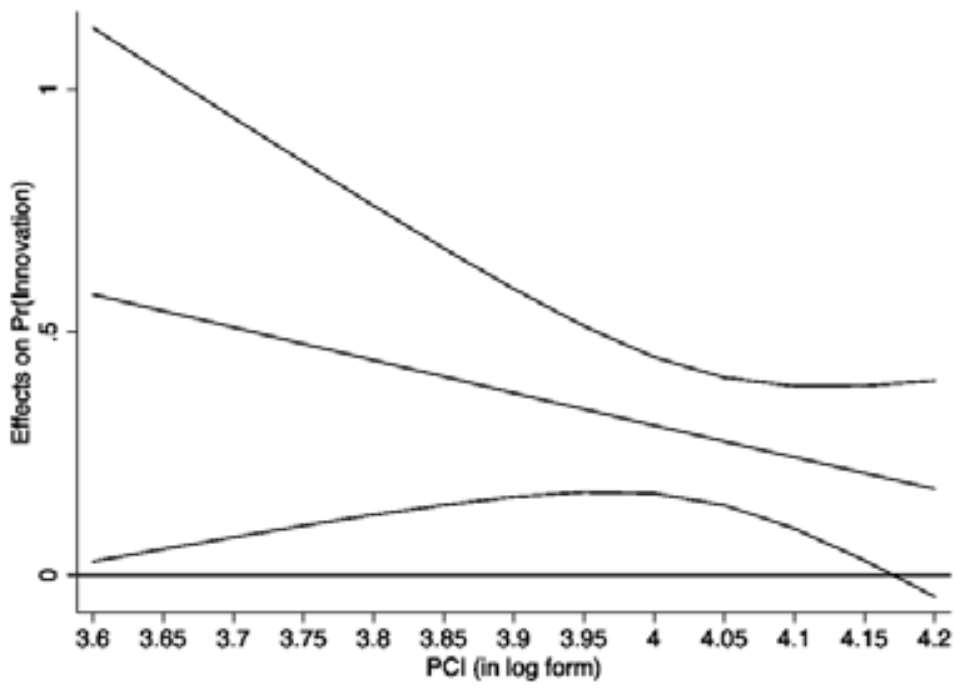

Figure 1. Marginal effects of local business environment ( $\mathrm{PCl}$ in log form) on innovation with $95 \%$ confidence intervals Source: Authors. 


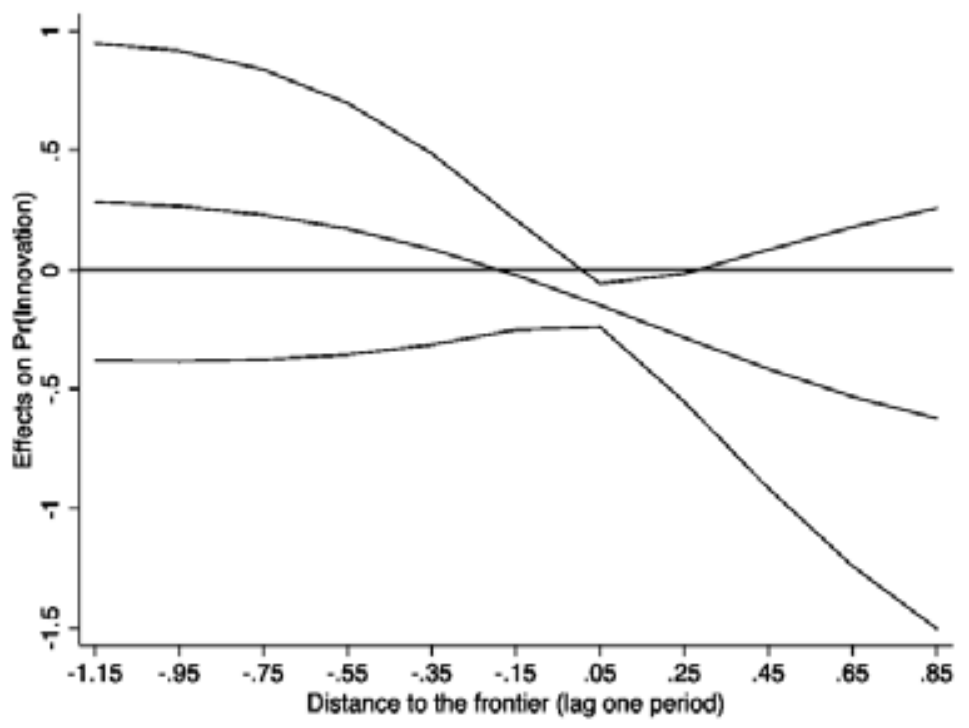

Figure 2. Marginal effects of distance to the frontier on innovation with $95 \%$ confidence intervals Source: Authors.

In Figure 2, the marginal effects of local business environment (proxy by $\mathrm{PCl}$ index in log form) on innovation are plotted over a range of value of one-period-lag distance to the frontier. The negative values of the marginal effects in this figure show that as the SMEs catch up with the frontier in their industries the negative effects of local business environment on innovation are getting higher. This finding is consistent with Figure 1, further indicating that an improved business environment is more beneficial for the laggard SMEs than those which are closer to the frontier in terms of achieving innovation.

To provide insights into diversified roles of local business environment in explaining the effects of distance to the frontier on innovation of the SMEs, we further divided our whole sample into sub-samples by size and age of the SMEs. With each sub-sample, we estimated the same Equation (2). Regressions results are presented in Tables 6, 7 and 8.

Table 6 reports the effects of distance to the frontier on innovation of the SMEs classified into micro enterprises, which have less than 10 workers, and non-micro enterprises. The results show that the negative moderating impact of the local business environment on the effects of distance to the frontier on general innovation is only statistically significant for micro enterprises, while it is not for non-micro enterprises. In combination with findings from Table 4, it suggests that improving the local business environment favours the laggards, especially those who are smaller in size. Findings in Table 7 are complementary to those reported in Table 5 for both groups, suggesting that better-quality local business environment supports both groups of enterprises to achieve incremental innovation. 
Table 6. Effects of distance to the frontier on general innovation of SMEs by size

\begin{tabular}{|c|c|c|}
\hline & $\begin{array}{c}\text { Micro enterprises } \\
\text { (1) }\end{array}$ & $\begin{array}{c}\text { Non-micro enterprises } \\
\text { (2) }\end{array}$ \\
\hline \multirow[t]{2}{*}{ Dist $_{t-1}$} & $24.229 *$ & 19.602 \\
\hline & $(1.75)$ & $(0.97)$ \\
\hline \multirow[t]{2}{*}{$\left.\ln P C\right|_{j t}$} & $-1.204 * *$ & $-3.050 * * *$ \\
\hline & $(2.47)$ & (3.93) \\
\hline \multirow[t]{2}{*}{ Dist $\left._{i t-1} \ln P C\right|_{j t}$} & $-6.047^{*}$ & -4.971 \\
\hline & $(1.76)$ & $(1.00)$ \\
\hline \multirow[t]{2}{*}{ Firm size } & $0.585^{* * *}$ & $0.344 * * *$ \\
\hline & (11.24) & (6.11) \\
\hline \multirow[t]{2}{*}{ Firm age } & $-0.222 * * *$ & $-0.345 * * *$ \\
\hline & (3.05) & $(2.83)$ \\
\hline Industry dummies & Yes & Yes \\
\hline Location dummies & Yes & Yes \\
\hline Year dummies & Yes & Yes \\
\hline \multirow[t]{2}{*}{ Constant } & $4.609 * *$ & $12.043^{* * *}$ \\
\hline & $(2.26)$ & (3.69) \\
\hline Observations & 7,742 & 2,917 \\
\hline
\end{tabular}

Note: Absolute value of $\mathrm{z}$ statistics in parentheses; *significant at $10 \%, * *$ significant at $5 \%$, $* * *$ significant at $1 \%$.

Source: Authors.

Table 7. Effects of distance to the frontier on specific types of innovation by the size of SMEs

\begin{tabular}{|c|c|c|c|c|c|c|}
\hline & \multicolumn{3}{|c|}{ Micro enterprises } & \multicolumn{3}{|c|}{ Non-micro enterprises } \\
\hline & $\begin{array}{c}\mathrm{New} \\
\text { product } \\
\text { (1) }\end{array}$ & $\begin{array}{l}\text { New } \\
\text { production } \\
\text { process } \\
(2)\end{array}$ & $\begin{array}{l}\text { Improvement } \\
\text { of existing } \\
\text { products } \\
\text { (3) }\end{array}$ & $\begin{array}{l}\text { New } \\
\text { product } \\
\text { (4) }\end{array}$ & $\begin{array}{l}\mathrm{New} \\
\text { production } \\
\text { process } \\
\text { (5) }\end{array}$ & $\begin{array}{l}\text { Improvement } \\
\text { of existing } \\
\text { products } \\
\text { (6) }\end{array}$ \\
\hline Dist $_{t-1}$ & $\begin{array}{c}-41.706 \\
(0.85)\end{array}$ & $\begin{array}{c}-35.176 \\
(1.26)\end{array}$ & $\begin{array}{l}26.350^{*} \\
(1.75)\end{array}$ & $\begin{array}{c}-27.808 \\
(0.78)\end{array}$ & $\begin{array}{c}19.427 \\
(0.93)\end{array}$ & $\begin{array}{l}42.655^{*} \\
(1.94)\end{array}$ \\
\hline$\left.\ln P C\right|_{j t}$ & $\begin{array}{l}-0.105 \\
(0.10)\end{array}$ & $\begin{array}{l}-2.030^{* *} \\
(2.32)\end{array}$ & $\begin{array}{l}-2.294^{* * *} \\
(4.09)\end{array}$ & $\begin{array}{l}-4.959 * * * \\
(3.62)\end{array}$ & $\begin{array}{l}-2.740 * * * \\
(3.00)\end{array}$ & $\begin{array}{l}-2.472^{* * *} \\
(3.07)\end{array}$ \\
\hline Dist $_{i t-1} \ln P C l_{j t}$ & $\begin{array}{l}10.122 \\
(0.85)\end{array}$ & $\begin{array}{c}8.447 \\
(1.22)\end{array}$ & $\begin{array}{l}-6.567^{*} \\
(1.75)\end{array}$ & $\begin{array}{c}7.065 \\
(0.80)\end{array}$ & $\begin{array}{l}-4.891 \\
(0.95)\end{array}$ & $\begin{array}{c}-10.816^{* *} \\
(1.99)\end{array}$ \\
\hline Firm size & $\begin{array}{c}0.049 \\
(0.59)\end{array}$ & $\begin{array}{l}0.919^{* * *} \\
(9.24)\end{array}$ & $\begin{array}{l}0.767^{* * *} \\
(12.25)\end{array}$ & $\begin{array}{l}0.303^{* * *} \\
(3.42)\end{array}$ & $\begin{array}{l}0.600^{* * *} \\
(8.81)\end{array}$ & $\begin{array}{l}0.266^{* * *} \\
(4.46)\end{array}$ \\
\hline Firm age & $\begin{array}{l}-0.050 \\
(0.44)\end{array}$ & $\begin{array}{l}-0.255^{*} \\
(1.94)\end{array}$ & $\begin{array}{l}-0.316^{* * *} \\
(3.59)\end{array}$ & $\begin{array}{l}-0.247 \\
(1.16)\end{array}$ & $\begin{array}{l}-0.632^{* * *} \\
(3.78)\end{array}$ & $\begin{array}{l}-0.294 * * \\
(2.22)\end{array}$ \\
\hline Industry dummies & Yes & Yes & Yes & Yes & Yes & Yes \\
\hline Location dummies & Yes & Yes & Yes & Yes & Yes & Yes \\
\hline Year dummies & Yes & Yes & Yes & Yes & Yes & Yes \\
\hline Constant & $\begin{array}{c}1.953 \\
(0.43)\end{array}$ & $\begin{array}{c}4.441 \\
(1.22)\end{array}$ & $\begin{array}{l}5.951 * * \\
(2.54)\end{array}$ & $\begin{array}{l}20.892^{* * *} \\
(3.65)\end{array}$ & $\begin{array}{l}8.468 * * \\
(2.20)\end{array}$ & $\begin{array}{l}7.629 * * \\
(2.25)\end{array}$ \\
\hline Observations & 7,742 & 7,742 & 7,742 & 2,917 & 2,917 & 2,917 \\
\hline
\end{tabular}

Note: Absolute value of $\mathrm{z}$ statistics in parentheses; ${ }^{*}$ significant at $10 \%, * *$ significant at $5 \%,{ }^{* * *}$ significant at $1 \%$.

Source: Authors. 
Table 8. Effects of distance to the frontier on specific types of innovation by age of SMEs

\begin{tabular}{|c|c|c|c|c|c|c|}
\hline & \multicolumn{3}{|c|}{ 1-20 years of establishment } & \multicolumn{3}{|c|}{$>20$ years of establishment } \\
\hline & $\begin{array}{l}\text { New } \\
\text { product } \\
\text { (1) }\end{array}$ & $\begin{array}{l}\text { New } \\
\text { production } \\
\text { process } \\
\text { (2) }\end{array}$ & $\begin{array}{l}\text { Improvement } \\
\text { of existing } \\
\text { products } \\
\text { (3) }\end{array}$ & $\begin{array}{l}\text { New } \\
\text { product } \\
\text { (4) }\end{array}$ & $\begin{array}{l}\text { New } \\
\text { production } \\
\text { process } \\
\text { (5) }\end{array}$ & $\begin{array}{l}\text { Improvement } \\
\text { of existing } \\
\text { products } \\
\text { (6) }\end{array}$ \\
\hline Dist $_{t-1}$ & $\begin{array}{c}-10.697 \\
(0.34)\end{array}$ & $\begin{array}{c}18.657 \\
(0.96)\end{array}$ & $\begin{array}{l}37.376 * * \\
(2.20)\end{array}$ & $\begin{array}{l}-0.115 \\
(0.00)\end{array}$ & $\begin{array}{r}-29.065 \\
(1.18)\end{array}$ & $\begin{array}{l}30.756 * \\
(1.75)\end{array}$ \\
\hline $\ln P C l_{j t}$ & $\begin{array}{l}-1.850 \\
(1.48)\end{array}$ & $\begin{array}{l}-1.379 \\
(1.49)\end{array}$ & $\begin{array}{l}-2.684^{* * *} \\
(3.72)\end{array}$ & $\begin{array}{l}-1.429 \\
(1.31)\end{array}$ & $\begin{array}{l}-2.849 * * * \\
(3.15)\end{array}$ & $\begin{array}{l}-2.316^{* * *} \\
(3.69)\end{array}$ \\
\hline Dist $_{i t-1} \ln P C l_{j t}$ & $\begin{array}{l}2.777 \\
(0.36)\end{array}$ & $\begin{array}{l}-4.849 \\
(1.01)\end{array}$ & $\begin{array}{l}-9.548^{* *} \\
(2.27)\end{array}$ & $\begin{array}{l}-0.509 \\
(0.04)\end{array}$ & $\begin{array}{l}7.252 \\
(1.19)\end{array}$ & $\begin{array}{l}-7.557^{*} \\
(1.73)\end{array}$ \\
\hline Firm size & $\begin{array}{l}0.226^{* * *} \\
(4.62)\end{array}$ & $\begin{array}{l}* 0.735^{* * *} \\
(16.71)\end{array}$ & $\begin{array}{l}0.467^{* * * *} \\
(13.36)\end{array}$ & $\begin{array}{l}0.158^{* *} \\
(2.50)\end{array}$ & $\begin{array}{l}0.684^{* * *} \\
(11.50)\end{array}$ & $\begin{array}{l}0.509^{* * *} \\
(11.44)\end{array}$ \\
\hline Firm age & $\begin{array}{l}0.103 \\
(0.44)\end{array}$ & $\begin{array}{l}-0.362 \\
(1.43)\end{array}$ & $\begin{array}{l}-0.237 \\
(1.28)\end{array}$ & $\begin{array}{l}-0.380^{*} \\
(1.66)\end{array}$ & $\begin{array}{l}-0.669 * * * \\
(2.96)\end{array}$ & $\begin{array}{l}-0.721^{* * *} \\
(4.76)\end{array}$ \\
\hline Industry dummies & Yes & Yes & Yes & Yes & Yes & Yes \\
\hline Location dummies & Yes & Yes & Yes & Yes & Yes & Yes \\
\hline Year dummies & Yes & Yes & Yes & Yes & Yes & Yes \\
\hline Constant & $\begin{array}{l}8.345 \\
(1.62)\end{array}$ & $\begin{array}{l}1.856 \\
(0.48)\end{array}$ & $\begin{array}{l}8.147 * * * \\
(2.70)\end{array}$ & $\begin{array}{l}7.760^{*} \\
(1.68)\end{array}$ & $\begin{array}{l}9.459 * * \\
(2.44)\end{array}$ & $\begin{array}{l}7.337^{* * *} \\
(2.71)\end{array}$ \\
\hline Observations & 5,557 & 5,557 & 5,557 & 5,102 & 5,102 & 5,102 \\
\hline
\end{tabular}

Note: Absolute value of $\mathrm{z}$ statistics in parentheses; ${ }^{*}$ significant at $10 \%, * *$ significant at $5 \%, * * *$ significant at $1 \%$.

Source: Authors.

The effects of distance to the frontier on various types of innovation of the SMES classified into a group of young SMEs, which have less than 20 years of establishment and older ones are reported in Table 8. The interaction term between distance to the frontier and the proxy for local business environment has a higher absolute value and more statistically significant in Column (3) than that in Column (6), indicating that improvement in local business environment favours weak and young SMEs in achieving incremental innovation.

\section{Concluding Remarks}

This study addresses an important issue and bridges the gap in the literature about how the local business environment can moderate the effects of distance to the frontier on innovation of enterprises by utilising a panel of data on SMEs conducted in Vietnam which is a transition economy. There are several findings from the study. First of all, in line with the existing literature, the study confirms a positive relationship between distance to the frontier in terms of productivity and innovation of the SMEs. In other words, SMEs in the top league are able to achieve more innovation. Secondly, the study finds strong evidence that an improved local business environment holds an important role in explaining the effects of distance to the frontier on innovation of the 
SMEs. Specifically, an improved local business environment favours innovation of the laggards which have productivity relatively much lower in comparison with the frontier. This finding is reasonable in transition economies as innovation achieved by the SMEs is likely to be incremental and not radical, which can be easily imitated by others. As a result, efforts of the public sector to improve business environment in transition economies are warranted for the successful development of the SMEs which account for the majority of number of enterprises in the private sector.

There are remaining limitations of the study. First of all, lacking a good instrumental variable (IV) has prevented us from conducting the 2SLS estimation method, which is more efficient in dealing with the endogeneity problem arising from reverse causality. Secondly, the dataset itself does not allow us to conduct further analysis about the effects of distance to the frontier on innovative activities, especially R\&D activities of the SMEs. Such an analysis would provide further insights into why some SMEs have tried but not been successful in innovation. Further, using a composite index, i.e. $\mathrm{PCl}$, to measure the local business environment for the analysis does not provide details about what particular elements of the local business environment should be improved. Finally, we could not separate the indirect and direct effects of local business environment on innovation of the SMEs. Such further findings are important for policymakers to have a better focus given limited resources available in transition economies when they want to develop the private sector. Future studies are greatly encouraged in these directions.

\section{References}

Acemoglu, D., Aghion, P., \& Zilibotti, F. (2006). Distance to frontier, selection, and economic growth. Journal of the European Economic Association, 4(1), 37-74. https://doi.org/10.1162/ jeea.2006.4.1.37

Acs, Z., \& Audretsch, D.B. (1990). Innovation and small firms. Cambridge, MA: The MIT Press.

Aghion, P., \& Howitt, P. (1992). A model of growth through creative destruction. Econometrica, 60(2), 323-351. https://doi.org/10.2307/2951599

Aghion, P., Bechtold, S., Cassar, L., \& Herz, H. (2014). The causal effects of competition on innovation: Experimental evidence (NBER Working Paper No. 19987). Cambridge, MA: National Bureau of Economic Research. https://doi.org/10.3386/w19987

Aghion, P., Bloom, N., Blundell, R., Griffith, R., \& Howitt, P. (2005). Competition and innovation: An inverted-U relationship. Quarterly Journal of Economics, 120(2), 701-728. https://doi. org/10.1093/qje/120.2.701

Aghion, P., Blundell, R., Griffith, R., Howitt, P., \& Prantl, S. (2006). The effects of entry on incumbent innovation and productivity (NBER Working Paper 12027). Cambridge, MA: National Bureau of Economic Research. https://doi.org/10.3386/w12027

Aghion, P., Harris, C., Howitt, P., \& Vickers, J. (2001). Competition, imitation and growth with step-by-step innovation. Review of Economic Studies, 68(3), 467-492. https://doi. org/10.1111/1467-937X.00177

Alder, S. (2010). Competition and innovation: Does the distance to the technology frontier matter? https://doi.org/10.2139/ssrn.1635789

Amable, B., Demmou, L., \& Ledezma, I. (2008). Competition, innovation and distance to frontier (Documents de travail du Centre d'Economie de la Sorbonne, 2008.64). Paris, France: Université Paris 1. Retrieved from https://halshs.archives-ouvertes.fr/halshs-00340409/ document 
Audretsch, D.B., Hülsbeck, M., \& Lehmann, E.E. (2012). Regional competitiveness, university spillovers, and entrepreneurial activity. Small Business Economics, 39, 587-601. https://doi. org/10.1007/s11187-011-9332-9

Balasubramanian, N., \& Lee, J. (2008). Firm age and innovation. Industrial and Corporate Change, 17(5), 1019-1047. https://doi.org/10.1093/icc/dtn028

Barbosa, N., \& Faria, A.P. (2011). Innovation across Europe: How important are institutional differences? Research Policy, 40(9), 1157-1169. https://doi.org/10.1016/j.respol.2011.05.017

Block, J.H., Fisch, C.O., \& van Praag, M. (2016). The Schumpeterian entrepreneur: A review of the empirical evidence on the antecedents, behaviour and consequences of innovative entrepreneurship. Industry and Innovation, 24(1), 61-95. https://doi.org/10.1080/13662716 .2016.1216397

Brouwer, E., Budil-Nadvornikova, H., \& Kleinknecht, A. (1999). Are urban agglomerations a better breeding place for product innovation? An analysis of new product announcements. Regional Studies, 33(6), 541-549. https://doi.org/10.1080/00343409950078233

Caballero, R.J., \& Jaffe, A.B. (1993). How high are the giants' shoulders: An empirical assessment of knowledge spillovers and creative destruction in a model of economic growth. NBER Macroeconomics Annual, 8, 15-74. https://doi.org/10.1086/654207

Coad, A., Segarra, A., \& Teruel, M. (2016). Innovation and firm growth: Does firm age play a role? Research Policy, 45(2), 387-400. https://doi.org/10.1016/j.respol.2015.10.015

Cobbenhagen, J. (2000). Successful innovation: Towards a new theory for the management of small and medium sized enterprises. Cheltenham, UK: Edward Elgar Publishing.

Conway, P., De Rosa, D., Nicoletti, G., \& Steiner, F. (2006). Regulation, competition and productivity convergence (OECD Economics Department Working Paper, No. 509). Retrieved from https:// doi.org/10.2139/ssrn.929677

Crepon, B., \& Duguet, E. (1997). Research and development, competition and innovation pseudo-maximum likelihood and simulated maximum likelihood methods applied to count data models with heterogeneity. Journal of Econometrics, 79(2), 355-378. https://doi. org/10.1016/S0304-4076(97)00027-4

Culbertson, J.D., \& Mueller, W.F. (1985). The influence of market structure on technological performance in the food-manufacturing industries. Review of Industrial Organization, 2(March), 40-54. https://doi.org/10.1007/BF02354365

Davidson, C., \& Segerstrom, P. (1998). R\&D subsidies and economic growth. The RAND Journal of Economics, 29(3), 548-577.

Edwards, T., Delbridge, R., \& Munday, M. (2005). Understanding innovation in small and mediumsized enterprises: A process manifest. Technovation, 25(10), 1119-1127. https://doi. org/10.1016/j.technovation.2004.04.005

Hölzl, W., \& Janger, J. (2014). Distance to the frontier and the perception of innovation barriers across European countries. Research Policy 43(4), 707-725. https://doi.org/10.1016/j. respol.2013.10.001

Hansen, J.A. (1992). Innovation, firm size, and firm age. Small Business Economics, 4, 37-44.

Huergo, E., \& Jaumandreu, J. (2004). How does probability of innovation change with firm age? Small Business Economics, 22(4), 193-207. https://doi.org/10.1023/B:SBEJ.0000022220. 07366.b5

Hwang, H., \& Powell, W.W. (2005). Institutions and entrepreneurship. In S.A. Alvarez, R. Agarwal, \& O. Sorenson (Eds.), Handbook of entrepreneurship research: Interdisciplinary perspectives (pp. 201-232). Boston, MA: Springer. https://doi.org/10.1007/0-387-23622-8_10

Kleinknecht, A., \& Poot, T.P. (1992). Do regions matter for R\&D? Regional Studies, 26(3), 221-232. https://doi.org/10.1080/00343409212331346921

Lunn, J., \& Martin, S. (1986). Market structure, firm structure, and research and development. Quarterly Review of Economics and Business, 26(1), 31-44. 
Malva, A.D., \& Santarelli, E. (2016). Intellectual property rights, distance to the frontier, and R\&D: Evidence from microdata. Eurasian Business Review, 6(1), 1-24. https://doi.org/10.1007/ s40821-015-0022-4

Mansfield, E. (1981). Composition of R and D expenditures: Relationship to size of firm, concentration, and innovative output. The Review of Economics and Statistics, 63(4), 610-615. https://doi.org/10.2307/1935857

Nguyen, A.N., Pham, N.Q., Nguyen, C.D., \& Nguyen, N.D. (2008). Innovation and exports in Vietnam's SME sector. The European Journal of Development Research, 20(2), 262-280. https://doi.org/10.1080/09578810802060801

Nhung, T. (2018, August 28). Bao Mot The Gioi. Retrieved from https://motthegioi.vn/khoa-hoccong-nghe-c-68/cong-bo-ket-qua-thong-ke-doi-moi-sang-tao-trong-dn-95541.html

North, D.C. (1990). Institutions, institutional change and economic performance. Cambridge, UK: Cambridge University Press.

Rothwell, R. (1985). Innovation and the smaller firm. Paper presented at the First International Technical Innovation and Entrepreneurship Symposium, Utah Innovation Foundation, Salt Lake City.

Scherer, F.M. (1965). Firm size, market structure, opportunity, and the output of patented inventions. The American Economic Review, 55(5), 1097-1125.

Schumpeter, J.A. (1934). The theory of economic development. Cambridge, MA: Harvard University Press.

Scott, J. (1984). Firm versus industry variability in R\&D intensity. In Z. Griliches (Ed.), R\&D, patents, and productivity (pp. 233-248). Cambridge, MA: National Bureau of Economic Research.

Slappendel, C. (1996). Perspectives on innovation in organizations. Organization Studies, 17(1), 107-129. https://doi.org/10.1177/017084069601700105

Sonobe, T., \& Otsuka, K. (2006). Cluster-based industrial development: An East Asian model. Basingtoke, UK: Palgrave Macmillan.

Sternberg, R., \& Arndt, O. (2001). The firm or the region: What determines the innovation behavior of European firms? Economic Geography, 77(4), 364-382. https://doi. org/10.1111/j.1944-8287.2001.tb00170.x

VCCI, U. (2018). Chỉ số năng lực cạnh tranh cấp tỉnh PCI 2017. Hanoi, Vietnam: NXB Thanh Nien.

Vo, V.D. (2015). The effects of local business environments on SMEs' performance: Empirical evidence from the Mekong Delta. Asian Academy of Management Journal, 20(1), 101-122.

Vossen, R.W. (1998). Research note: Relative strengths and weaknesses of small firms in innovation. International Small Business Journal, 3, 88-94.

Vu, H.N., \& Hoang, B.T. (2019). Business environment and innovation persistence: The case of small- and medium-sized enterprises in Vietnam. Economics of Innovation and New Technology, 28(8), 1-23. https://doi.org/10.1080/10438599.2019.1689597

World Bank. (2017). The World Bank data. Retrieved from https://data.worldbank.org/indicator / NY.GDP.DEFL.ZS?locations $=\mathrm{VN}$

Zeng, J. (2001). Innovative vs. imitative R\&D and economic growth. Journal of Development Economics, 64(2), 499-528. https://doi.org/10.1016/S0304-3878(00)00148-6 
